\title{
COVID-19 outbreak in Brazil: adherence to national preventive measures and impact on people's lives, an online survey
}

\author{
Edlaine Faria de Moura Villela ${ }^{1 *}$ (D), Rossana Verónica Mendoza López² ${ }^{2}$ Ana Paula Sayuri Sato ${ }^{3}$, \\ Fábio Morato de Oliveira', Eliseu Alves Waldman ${ }^{3}$, Rafael Van den Bergh ${ }^{4}$, Joseph Nelson Siewe Fodjo ${ }^{4}$ and \\ Robert Colebunders ${ }^{4}$
}

\begin{abstract}
Background: The first case of COVID-19 infection was diagnosed in Brazil 26th February 2020. By March 16th, physical distancing and confinement measures were implemented by the Brazilian government. Little is known about how these measures were followed up by the Brazilian people and their impact on daily routine.

Methods: In early April 2020, using an online platform, we organized an online survey among adults living in Brazil about their COVID-19 preventive behavior and impact on their daily routine.

Results: Data from 23,896 respondents were analyzed (mean age: 47.4 years). Due to COVID-19 restrictions, half (51.1\%) of the professionals reported working from home. Regular handwashing was practiced by $98.7 \%$ of participants; $92.6 \%$ reported adhering to the $1.5-2 \mathrm{~m}$ physical distancing rule, but only $45.5 \%$ wore a face mask when going outside. While $29.3 \%$ of respondents found it relatively easy to stay at home, indoor confinement was extremely difficult for $7.9 \%$ of participants. Moreover, $11 \%$ of participants were extremely worried about their health during the COVID-19 epidemic. Younger people, male, persons living in a rural area/village or popular neighbourhoods, students and workers reported less preventive behaviour.
\end{abstract}

Conclusion: Restrictive measures markedly affected the daily and professional routines of Brazilians. Participants showed a satisfactory level of adherence to national COVID-19 prevention guidelines. Qualitative and follow-up studies are needed to monitor the impact of COVID-19 in the Brazilian society.

Keywords: Prevention, Behavior, pandemics, Public health, surveillance, COVID-19, South America

\section{Background}

On December 31st 2019, the World Health Organization (WHO) received a notification of an unknown viral pneumonia outbreak in the Hubei Province of China. This outbreak was later found to be caused by the Severe Acute Respiratory Syndrome Coronavirus $2[1,2]$. The disease, now called Coronavirus Disease 2019

\footnotetext{
* Correspondence: edlaine@ufg.br

'School of Medicine, Health Sciences Unit, Federal University of Jataí, Jataí, Brazil

Full list of author information is available at the end of the article
}

(COVID-19), has quickly spread to most countries of the world, affecting almost 5 million individuals and causing more than 320,000 deaths. Until May 22, 492,124 cases were registered in the South America, with $55,3 \%$ being in Brazil [3].

COVID-19 is primarily transmitted by respiratory droplets with a similar incubation time and development time as the previously known Severe Acute Respiratory Syndrome Coronavirus (SARS-CoV) [1, 4]. The rapid international spread of COVID-19 pressured the WHO to declare the COVID-19 epidemic as a public health

(c) The Author(s). 2021 Open Access This article is licensed under a Creative Commons Attribution 4.0 International License, which permits use, sharing, adaptation, distribution and reproduction in any medium or format, as long as you give appropriate credit to the original author(s) and the source, provide a link to the Creative Commons licence, and indicate if changes were made. The images or other third party material in this article are included in the article's Creative Commons licence, unless indicated otherwise in a credit line to the material. If material is not included in the article's Creative Commons licence and your intended use is not permitted by statutory regulation or exceeds the permitted use, you will need to obtain permission directly from the copyright holder. To view a copy of this licence, visit http://creativecommons.org/licenses/by/4.0/ The Creative Commons Public Domain Dedication waiver (http://creativecommons.org/publicdomain/zero/1.0/) applies to the data made available in this article, unless otherwise stated in a credit line to the data. 
emergency of international importance in late January 2020. Such a decision is taken when an event with major public health implications crosses the borders of the country initially affected, demanding immediate international action [5]. In the absence of antivirals and while awaiting the large-scale introduction of COVID-19 vaccination [6], various public health strategies to contain the infection have been implemented around the world. These strategies commonly consist of enforced or semienforced "lockdowns" and closure of national and/or intra-national borders, as well as promotion of respiratory hygiene (masking, coughing/sneezing etiquette) and hand hygiene. The package of containment measures for COVID-19 around the world probably represents the largest global public health intervention in human history, though the societal and individual impact of these measures is not yet well-understood.

The population-level adherence to such measures may determine to a considerable extent the national magnitude and duration of the COVID-19 pandemic [7, 8]. However, little is known on population-level adherence to the various containment measures implemented worldwide, with most studies focusing on adherence to hygiene measures among healthcare workers [9-11]. Indepth documentation of adherence to containment measures is nonetheless essential, on the one hand to feed into initiatives attempting to model outbreaks [7, 12], and on the other hand to adapt and target health promotion messages to sub-populations that may be struggling to adhere to specific measures [13], such as specific age groups.

In Brazil, the first case of COVID-19, reported by the Ministry of Health $(\mathrm{MOH})$ on February 26th, was a 61year-old man who had traveled to Italy between February 9 and 21 of 2020. Two tests were positive for COVID-19 infection. Since then, the number of infected persons in Brazil has increased dramatically [14]. Physical distancing and confinement measures were implemented by the Brazilian government after COVID-19 was declared a pandemic on March 16th [5]. Events expected to attract large numbers of people were cancelled, universities and schools were closed, and only services considered essential to the population remained functional, such as markets, pharmacies and bakeries. However, traveling between Brazilian states remained possible. To document how the containment measures affected the lives of the Brazilian people, and to understand which containment measures were best adhered to by which strata of the population, we conducted an online survey on the adherence of the Brazilian people to individual public health measures and impact of the COVID-19 outbreak on people's lives. A particular emphasis was placed on age as a stratifying factor, considering the clear association of COVID-19 severity with age, and the general need for adapting health messaging to specific age groups.

\section{Materials and methods Study design}

An online questionnaire survey was organized in Brazil between April 3 to April 9. At the time of the survey Brazil counted 9056 confirmed COVID-19 cases, 1769 hospitalizations and 359 deaths. Data were collected on the ICPcovid website (www.icpcovid.com), which is a secure web-based platform developed by the University of Antwerp, Belgium.

The link for the survey was disseminated using WhatsApp, email, and social media such as Facebook, Instagram, LinkedIn and ResearchGate. Furthermore, we had support from national organizations such as the Research Support Foundation of the State of Goiás, the Regional Council of Biology of the First Region, and the Faculty of Public Health of the University of São Paulo who actively disseminated the survey link. Everybody in Brazil, regardless their nationality could participate in the study: the only exclusion criteria for participation were being younger than 18 years (as we considered that approval from one of the parents was needed) and not living in Brazil at the moment of the survey.

The structured questionnaire consisted of 60 questions about socio-demographic characteristics, individual preventive measures (such as hand and respiratory hygiene, physical distancing and isolation) and daily living practices (such as impact on working conditions, difficulties to adhere to the preventive measures and COVID-19 health concerns); See supplemental information. We used Likert scores for questions concerning health risk perception and the level of difficulty to observe the preventive measures.

\section{Data analysis}

Statistical analysis was performed using IBM SPSS version 25 for Windows. Containment measures were grouped into three main categories: hand hygiene, respiratory hygiene, and physical distancing/isolation. A composite adherence score was generated for each of these categories using specific questions from the survey, with empirical weights (Table 1). Subsequently an overall adherence score was generated by combining the sub-scores using equal weights (1:1:1 ratio).

Descriptive statistics were presented using means with standard deviation (SD) for continuous outcomes, and percentages (\%) for categorical variables. The Wilcoxon test was used to compare the number of days of work per week before and after the epidemic.

Multiple linear regression was performed to analyze factors associated with adherence to national prevention restrictive measures; the composite adherence score 
Table 1 Composite adherence score to COVID-19 preventive measures

\begin{tabular}{ll}
\hline Preventive measures & Composite adherence score \\
\hline Hand hygiene & 1 \\
Wash hands regularly with water and soap OR with alcohol gel & 0.5 \\
Avoid touching face & 0.5 \\
Disinfect cell phone & Divide total score by 2 \\
Respiratory hygiene & 1 \\
Wear a face mask when leaving home & 1 \\
Covering face or nose with forearm or tissue when sneezing or coughing & 1 \\
Wash hands after coughing/sneezing & Divide total score by 3 \\
Physical distancing/isolation & 1 \\
Follow rule of staying 1.5-2 m from other people & 0.5 \\
Measure temperature twice a week & 1 \\
Stay home when experiencing flu-like symptoms (among people who had flu-like symptom days) & Divide total score by 2.5 \\
Overall composite score across all measures (1:1:1 ratio of specific scores) &
\end{tabular}

(Table 1) served as dependent variable. Variables with $p<0.10$ in bivariate analysis were included in the adjusted model, and the final model was selected via a backward stepwise process of eligible covariates. Covariates that were investigated included: age, gender, state and area of residence, education, marital status, living alone, profession, working in the health sector, and existing comorbidities. The significance level adopted was $5 \%$ for all hypothesis tests.

\section{Results}

\section{Characteristics of respondents}

A total of 25,266 persons participated in the survey. After excluding respondents younger than 18 years $(n=$ 163) and people with inconsistent responses (1207), 23, 896 respondents $(94.6 \%)$ were included for analysis. Participants were from all parts of the country. The median age of participants was 48.0 years (IQR 37.0-58.0 years); $71.8 \%$ were women (Table 2). 7020 (29.4\%) reported a chronic underlying disease such as diabetes, cancer, HIV infection or tuberculosis and 2177 were smokers of cigarettes.

\section{Impact of COVID-19 restrictive measures on working arrangements}

At the time of the survey, $44.6 \%$ of professionals were working from home. For those who were not working from home, $66.1 \%$ were not able to do so because of the type of job, $9.1 \%$ were not allowed by their employer, $5 \%$ had to leave the house to make money to support the family, and $1.3 \%$ left the home because they considered this to be without a risk (Table 3). Due to COVID-19 restrictions, participants reported going to work less often (mean number of days of work per week: 0.8) compared to the period before the epidemic (mean number of days of work per week: 3.2; $p$-value $<0.001$; Wilcoxon test).

\section{Adherence to the national COVID-19 restrictions}

Most participants (92.6\%) reported adhering to the 1.5$2 \mathrm{~m}$ social distancing rule; $69.5 \%$ covered their mouth and nose when they sneeze and washed their hands afterwards; $45.5 \%$ wore a face mask when going outside; Staying at home was found to be extremely difficult for $7.9 \%$, but $29.3 \%$ considered it not difficult at all (Table 4).

\section{Difficulty to adhere to the COVID-19 preventive measures and health concerns}

While $29.3 \%$ of respondents found it relatively easy to stay at home, indoor confinement was extremely difficult for $7.9 \%$ of participants (Table 3). When queried about their health concerns as a consequence of COVID-19, respondents were more concerned about the health of their loved ones (29.9\% very concerned and $22.2 \%$ concerned) than their own health $(11.0 \%$ very concerned and $13.9 \%$ concerned) (Fig. 1).

Multiple linear regression analysis was carried out to identify factors associated with higher overall adherence. Older age, being female, having at least an undergraduate degree, being a health care worker, having comorbidities, not living in the rural area/village, not being a student, not working in the private sector, and not 
Table 2 Characteristics of study participants in an online survey on COVID-19, Brazil, April 2020

\begin{tabular}{|c|c|c|c|}
\hline \multirow{2}{*}{$\begin{array}{l}\text { Characteristics } \\
\text { Continuous variables }\end{array}$} & \multicolumn{3}{|l|}{$N=23,896$} \\
\hline & & & \\
\hline \multicolumn{4}{|l|}{ Age in years } \\
\hline & Median (Q1-Q3) & $48(37-58)$ & \\
\hline & Range & $18-89$ & \\
\hline Categorical variables & & $\mathbf{N}$ & $\%$ \\
\hline \multirow[t]{3}{*}{ Age group } & $18-25$ years & 1652 & 6.9 \\
\hline & $26-65$ years & 20,109 & 84.2 \\
\hline & $>65$ years & 2135 & 8.9 \\
\hline \multirow[t]{2}{*}{ Gender } & Male & 6741 & 28.2 \\
\hline & Female & 17,155 & 71.8 \\
\hline \multirow[t]{6}{*}{ Brazilian region of residence } & North & 299 & 1.3 \\
\hline & Northeast & 2315 & 9.7 \\
\hline & Central-West & 2489 & 10.4 \\
\hline & Southeast & 13,447 & 56.3 \\
\hline & South & 3428 & 14.3 \\
\hline & Not answered / missing data & 1918 & 8.0 \\
\hline \multirow[t]{2}{*}{ Nationality } & Brazilian & 23,746 & 99.4 \\
\hline & Foreign & 150 & 0.6 \\
\hline \multirow[t]{5}{*}{ Highest educational level } & I didn't complete elementary school & 1 & 0.0 \\
\hline & Primary School & 99 & 0.4 \\
\hline & Secondary School & 2437 & 10.2 \\
\hline & University Undergraduate degree holder & 7604 & 31.8 \\
\hline & University Postgraduate degree holder & 13,755 & 57.6 \\
\hline \multirow[t]{5}{*}{ Marital status } & Single & 5876 & 24.6 \\
\hline & Legally married & 12,167 & 50.9 \\
\hline & Cohabitation & 2556 & 10.7 \\
\hline & Divorced & 2713 & 11.4 \\
\hline & Widow/widower & 584 & 2.4 \\
\hline \multirow[t]{4}{*}{ Residential setting } & Downtown area & 13,046 & 54.6 \\
\hline & Suburb area & 4531 & 19.0 \\
\hline & Rural area/village & 631 & 2.6 \\
\hline & Popular neighborhoods & 5688 & 23.8 \\
\hline
\end{tabular}

smoking were all independently associated with a higher overall score (Table 5).

Adherence scores for the specific measures were all significantly lower in the younger age group (18-25 years). Respiratory hygiene and physical distancing adherence scores were significantly lower in the 26-65 years old than in the $>65$ years old - confounding of the other covariates was controlled for through multiple linear regression (Fig. 2).

\section{Discussion}

Our study shows that, during the survey period, Brazilians were following the COVID-19 preventive measures relatively well. Hand hygiene measures were adhered to most, followed by physical distancing and respiratory hygiene. In all categories of measures, a clear age effect was observed, with younger individuals scoring lower than older respondents on the adherence score.

Overall, only $45.5 \%$ reported wearing a face mask when going out. This is much lower than in Asian countries, where most people wore face masks once the COVID-19 epidemic was introduced in their country [15-17]. This is also lower than the $91.7 \%$ face mask use reported in a similar online survey in Ecuador in April 2020 and the $99.8 \%$ face mask use in a survey in Peru in June 2020 [18]. This is however higher than in several 
Table 3 Impact of COVID-19 restrictions on working conditions

\begin{tabular}{|c|c|c|c|}
\hline Characteristics & Description & $\mathrm{n}$ & $\%$ \\
\hline \multirow[t]{6}{*}{ Profession $(n=23,896)$} & Unemployed & 938 & 3.9 \\
\hline & Student & 1551 & 6.5 \\
\hline & Self-employed & 5235 & 21.9 \\
\hline & Work for the government (federal, state, municipal) & 7028 & 29.4 \\
\hline & Work for a person, institution or company & 5200 & 21.8 \\
\hline & Other & 3944 & 16.5 \\
\hline \multirow[t]{2}{*}{ Healthcare worker $(n=23,896)$} & Yes & 7293 & 30.5 \\
\hline & No & 16,603 & 69.5 \\
\hline \multirow[t]{5}{*}{ Current working conditions ( $n=21,407$ workers) } & Work from home & 9544 & 44.6 \\
\hline & Work in an open space (market, shop, roadside, etc) & 1452 & 6.8 \\
\hline & Work in a closed indoor space with several people (office, etc.) & 5614 & 26.2 \\
\hline & Work in a closed indoor space alone (office, etc.) & 1833 & 8.6 \\
\hline & Not informed & 2964 & 13.8 \\
\hline \multirow[t]{5}{*}{ Reasons for not working from home ( $n=5931$ workers) } & It is not possible with my job & 3918 & 66.1 \\
\hline & It is possible, but is not allowed by my employer & 540 & 9.1 \\
\hline & I don't think there is any risk to go out & 76 & 1.3 \\
\hline & I have to leave the house to make money to support my family & 298 & 5.0 \\
\hline & Other & 1099 & 18.5 \\
\hline
\end{tabular}

European countries where wearing face masks was initially advised only in health care settings, following WHO recommendations at the time [19-21]. Checking one's temperature for the early detection of a COVID-19 infection at least twice a week was only practiced by $10.8 \%$ of the respondents. This may be a point of concern, as WHO reported that temperature screening was able to detect the majority of exported cases during the COVID-19's expansion [22].

When assessing the profile of individuals with poor general adherence, men were less adherent compared to women, which mirrors findings from a Knowledge, Attitudes, and Practices study conducted in China (17). In our study, younger age was also associated with a lower

Table 4 Adherence to national anti-COVID-19 preventive measures

\begin{tabular}{|c|c|c|c|}
\hline & $n=23,896$ & $\mathbf{N}$ & $\%$ \\
\hline I follow the social $1.5-2 \mathrm{~m}$ meters distance rule & Yes & 22,117 & 92.6 \\
\hline I wear a face mask when going outside & Yes & 10,876 & 45.5 \\
\hline Covering face or nose with forearm or tissue when sneezing or coughing & Yes & 22,515 & 94.2 \\
\hline When I cough/sneeze, I usually wash/disinfect my hands soon after & Yes & 16,618 & 69.5 \\
\hline I measure my body temperature at least twice a week & Yes & 2586 & 10.8 \\
\hline I wash my hands using soap and water regularly during the day & Yes & 23,591 & 98.7 \\
\hline I use a hand sanitizer regularly during the day & Yes & 17,758 & 74.3 \\
\hline I avoid touching my face (eyes, nose and mouth) & Yes & 18,549 & 77.6 \\
\hline I disinfect my phone whenever I return home & Yes & 16,454 & 68.9 \\
\hline I travelled to another city/country during the last 7 days & Yes & 1339 & 5.6 \\
\hline \multicolumn{4}{|c|}{ Individual difficulty level to adhere to the national preventive measures for COVID-19 ( $1=$ not difficult at all to $5=$ extremely difficult) } \\
\hline & 1 & 6990 & 29.3 \\
\hline & 2 & 5651 & 23.6 \\
\hline & 3 & 6249 & 26.2 \\
\hline & 4 & 3113 & 13.0 \\
\hline & 5 & 1893 & 7.9 \\
\hline
\end{tabular}




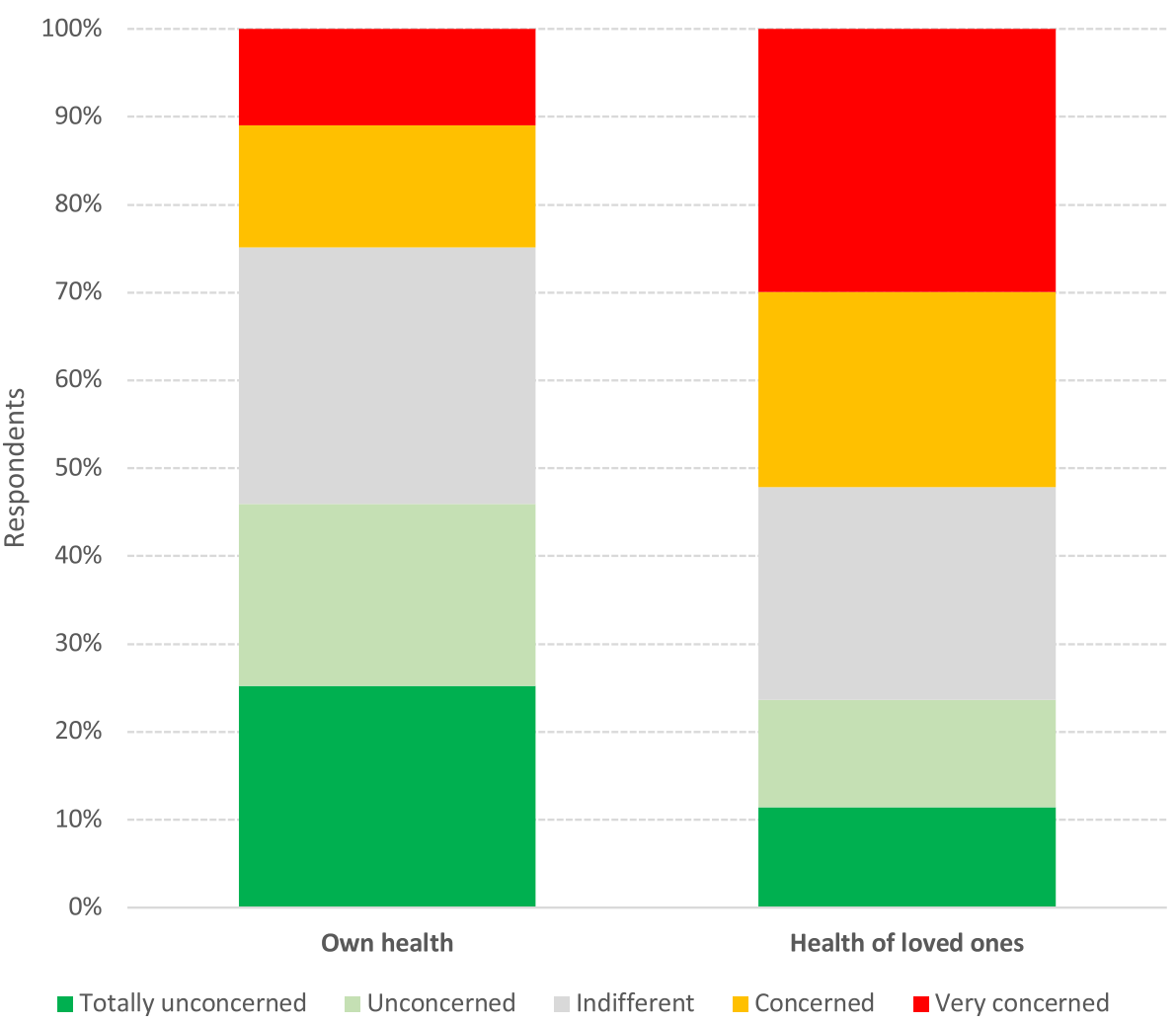

Fig. 1 Level of concern about COVID-19 consequences among participants of an online survey on COVID-19, Brazil, April 2020 (bivariate: selfversus loved ones)

overall score. In another large online survey in Brazil conducted between April 24th and May 24th, assessing only the degree of adherence to physical contact restriction measures, greater adherence was found among females compared to males but it was mainly the 30 to 49 year old group that was less adherent and not the younger age group [23]. People living in rural areas and poor neighborhoods were also less adherent: in rural areas people may not perceive themselves at high risk of COVID-19, and therefore may not respect the national restriction measures and not practice individual hygiene measures [24]. Therefore, extra communication and health education may be needed to change the risk perception in rural areas and popular neighborhoods [25]. Brazilian students reported difficulties to stay home, which may be related to a need to travel to their original homes in periods when schools and universities were closed [26] or could be related to differing social habits among this population. Encouragingly, respondents with underlying diseases followed the preventive measures well, which is important considering their higher risk for more severe disease.

Taken together, these observations suggest that tailoring of the public health messages may be indicated. A reinforcement of specific messages, such as mask use and temperature taking, may be beneficial, and using delivery methods tailored to the specific age groups could allow higher uptake. Especially communication methods to the younger age group could benefit from such tailoring, and possibly approaches relying on social media and including influencers to spread public health messages could be considered [27]. Of note, the observation that most respondents' concern was higher for their loved ones than for themselves could be incorporated in such health messages; possibly by emphasizing how adhering to measures protects one's close environment.

In general, our results indicate that following an intensive COVID-19 prevention campaign [28] the Brazilians gradually became aware of the importance of adopting simple methods to prevent COVID-19 transmission. For only $7.9 \%$ of the respondents indoor confinement was experienced as extremely difficult. Initially the $\mathrm{MOH}$ of Brazil expected a peak of COVID-19 infections during the second half of April. However, it did not happen. The satisfactory adherence to the preventive measures may have delayed the peak of the epidemic.

COVID-19 associated mortality during the study period was highest in the North region of Brazil (Amazonas) and in two states in the Northeast (Ceará and Pernambuco) [29]. Our study showed that the Northeast 
Table 5 Factors associated with adherence to national prevention restrictive measures

\begin{tabular}{|c|c|c|c|c|c|}
\hline Variable & Categories & B & Standard Error & $95 \% \mathrm{Cl}$ & $p$-value \\
\hline \multicolumn{6}{|l|}{$n=23,896$} \\
\hline & Intercept & 1.743 & 0.0473 & $1.650-1.836$ & $<0.001$ \\
\hline Age & (in years) & 0.007 & 0.0002 & $0.006-0.007$ & $<0.001$ \\
\hline \multirow[t]{2}{*}{ Gender } & Male & & & & \\
\hline & Female & 0.128 & 0.0063 & $0.116-0.141$ & $<0.001$ \\
\hline \multirow[t]{4}{*}{ Education } & Primary School or less & & & & \\
\hline & Secondary School & 0.059 & 0.0445 & $-0.028-0.146$ & 0.184 \\
\hline & Undergraduate & 0.099 & 0.0439 & $0.013-0.186$ & 0.023 \\
\hline & Postgraduate & 0.141 & 0.0439 & $0.055-0.227$ & 0.001 \\
\hline \multirow[t]{4}{*}{ Area of residence } & Downtown area & & & & \\
\hline & Suburban area & -0.007 & 0.0075 & $-0.022-0.006$ & 0.295 \\
\hline & Rural area/village & -0.086 & 0.0178 & $-0.117--0.048$ & $<0.001$ \\
\hline & Popular neighborhoods & -0.004 & 0.0071 & $-0.018-0.009$ & 0.552 \\
\hline \multirow[t]{6}{*}{ Profession } & Unemployed & & & & \\
\hline & Student & -0.058 & 0.0186 & $-0.095--0.022$ & 0.002 \\
\hline & Self-employed & 0.011 & 0.0156 & $-0.018-0.042$ & 0.453 \\
\hline & Work for the government (federal, state, municipal) & -0.022 & 0.0154 & $-0.052-0.008$ & 0.150 \\
\hline & Work for a person, institution or company & -0.045 & 0.0155 & $-0.075--0.015$ & 0.003 \\
\hline & None of the previous & 0.002 & 0.0164 & $-0.029-0.034$ & 0.885 \\
\hline \multirow[t]{2}{*}{ Health care worker } & No & & & & \\
\hline & Yes & 0.044 & 0.0065 & $0.031-0.056$ & $<0.001$ \\
\hline \multirow[t]{2}{*}{ Smoking } & No & & & & \\
\hline & Yes & -0.024 & 0.0098 & $-0.043--0.0047$ & 0.015 \\
\hline \multirow[t]{2}{*}{ Comorbidities } & Not that I know & & & & \\
\hline & Yes & 0.030 & 0.0064 & $0.017-0.043$ & $<0.001$ \\
\hline
\end{tabular}

region had less difficulty to adhere the restrictive measures. This difference between regions may have been influenced by the adoption of restrictive measures to varying degrees by the governors of the Brazilian states. Indeed, 11 states have decreed lockdown for at least one municipality in their state. Only the state of Amapá decreed a lockdown for all your municipalities.

There has been a lot of confusion about how to deal with the COVID-19 epidemic in Brazil. The president has minimized the actions of the $\mathrm{MOH}$, downplaying the importance of quarantine, and is defending vertical isolation to avoid financial collapse. Vertical isolation or shielding implies that most people return back to normal life and people with underlying diseases, older adults and pregnant women continue to respect physical distance and reduce their social activities. Regarding this vulnerable group, $29.4 \%$ stated to have underlying diseases in our survey. This is a concern, as older age and the presence of (an) underlying health condition(s) are associated with increased COVID-19 related mortality
$[30,31]$ On the other hand, Brazilian respondents with underlying diseases adhered better to the containment measures.

The lack of unified actions against COVID-19, by the federal government, led to the resignation of the health minister on April 16 [32, 33]. From that moment on, there was a relaxation of quarantine measures, opening of part of the trade, and consequently less physical distancing. The lack of national coordination by the government in response to the pandemic reveal the conflictual positions between the federal government and governors from the 27 states of the country [34]. This increased the number of COVID-19 cases and associated deaths [30, 31].

At the end of April, the COVID-19 death toll in Brazil had already exceeded that of China [3] (more than 5000 deaths) and this scenario got worse, not reaching the flattening of the curve and overloading the Brazilian health system [35]. As of December 31th 2020, more than 7,000,000 cases had been confirmed in the country, causing almost 200,000 deaths [3]. 


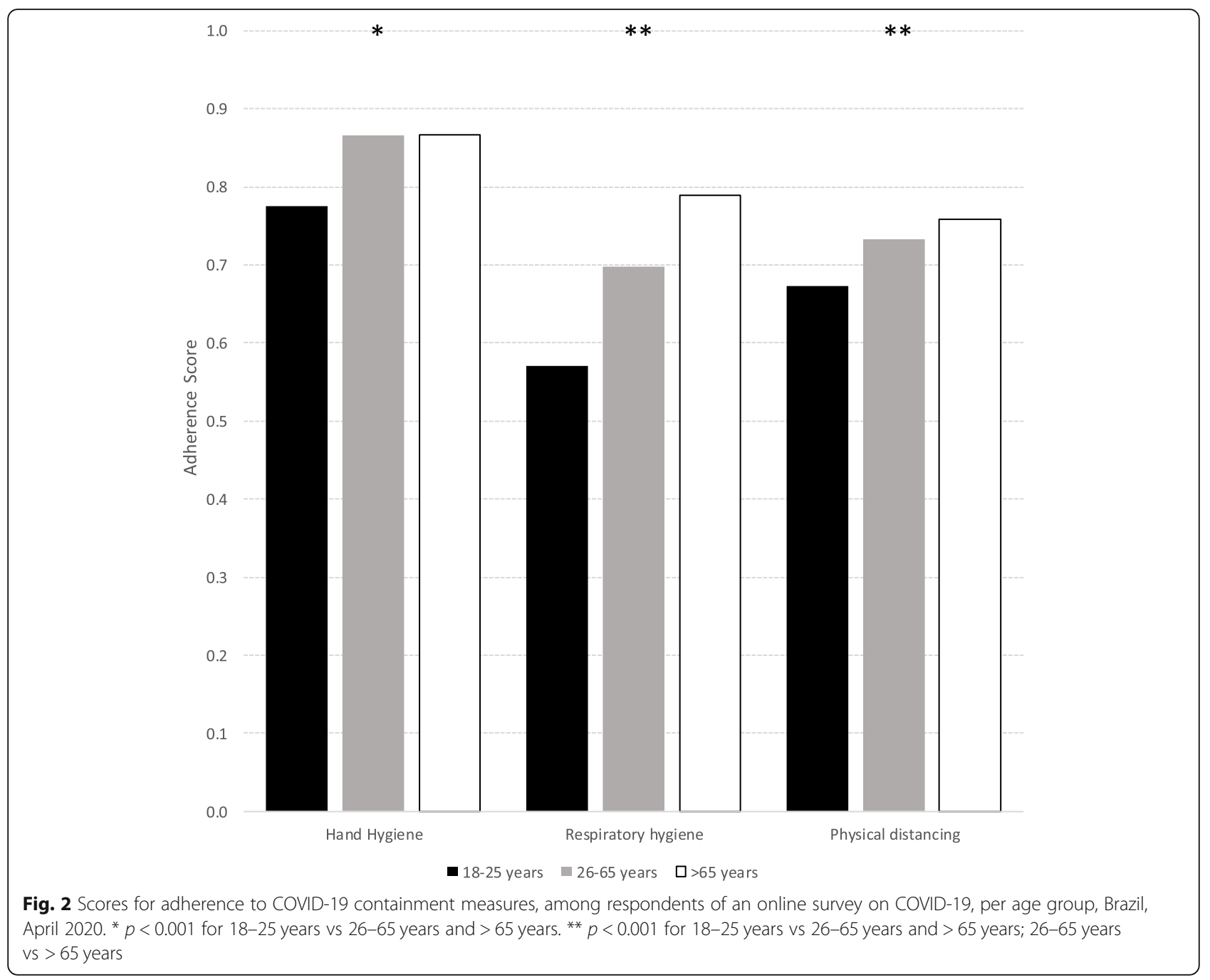

Our findings suggest a considerable initial willingness of the Brazilian people to follow the quarantine and other containment measures. However, this willingness seems to have been irrevocably subverted through the political stance against the public health measures with as a consequence that currently South America became the new epicenter of the pandemic with Brazil as the most affected country [3].

Our study had several limitations. The number of respondents was relatively small compared to the entire Brazilian population, and respondents were unevenly spread over the national territory. Indeed, only $2,6 \%$ of the participants reported residing in rural areas. The reason for this low number of participants from rural areas most likely is because in those areas people have less internet access and consequently are less linked to social media [24, 25]. While $51.8 \%$ of the Brazilian population are women [36], 71,8\% of the respondents in our survey were female. Such a higher proportion of female respondents was also observed in other studies on COVID-19- related practices [17]. Participants were more likely to be higher educated individuals living in cities and in the Southeast region. The latter may be explained by the fact that since the beginning of the pandemic, this region recorded the largest number of COVID-19 infections. Moreover, broadband internet quality is best in the Southeast region [37]. Our survey was also not able to reach vulnerable populations, such as the homeless, prisoners, older adults, migrants and people with mobility problems. Such populations may be at increased risk for COVID-19 infection and should be considered as priority key groups in the prevention and control of Covid-19 $[26,38]$. Our study findings are based on self-reports without a possibility to verify whether these responses corresponded with the real preventive behaviour of the respondents.

At the time of writing, the COVID-19 vaccination started in more than 30 countries [39], and in Brazil, it is scheduled to start at the end of January 2021. However, it will still be challenging to deal with the vaccine 
hesitance movements and the political polarization [40] that it is taking place in relation to vaccination.

\section{Conclusion}

In conclusion, most participants in this survey correctly followed the COVID-19 prevention guidelines, although staying at home was difficult for individuals who had to go out because of their job, and younger individuals tended to adhere less to containment measures. Larger follow-up surveys and in-depth qualitative studies about the preventive behavior of different groups in the Brazilian society are needed. The adherence to COVID-19 preventive measures will need to be monitored closely as restrictive measures are being relaxed and as the expectations concerning the COVID-19 vaccine may decrease the motivation of people to adhere to prevention measures.

\section{Supplementary Information}

The online version contains supplementary material available at https:/doi. org/10.1186/s12889-021-10222-z

Additional file 1. Survey questionnaire

\section{Abbreviations}

COVID-19: Coronavirus Disease 2019; MOH: Ministry of Health; SD: Standard deviation; WHO: World Health Organization

\section{Acknowledgements}

Special thanks to the Epidemiology and Health Services Observatory (EpiServ Team, Brazil) and to the Epidemiology and Public Health Research Group (EPICOL/CNPq, Brazil).

\section{Ethical approval and consent to participate}

The study was conducted in accordance with the Declaration of Helsinki and the protocol was approved by the National Research Ethics Commission, Brazil (Protocol number: 30343820.9.0000.0008, dated April 01, 2020). The need for consent was waived by the National Research Ethics Commission, according to national regulations (Resolution Number 466, December 12, 2012)

\section{Authors' contributions}

EFMV and RC conceived the study, coordinated the analysis and wrote the first draft of the manuscript. RVML and APSS conducted the statistical analysis and contributed to the interpretation of data. FMO and EAW provided important contributions to the design of the work and revised it substantively. RVdB and JNSF provided analysis, editorial support and revised it. All authors critically reviewed and approved the submitted version (and any substantially modified version that involves the author's contribution to the study); All authors have agreed both to be personally accountable for the author's own contributions and to ensure that questions related to the accuracy or integrity of any part of the work, even ones in which the author was not personally involved, are appropriately investigated, resolved, and the resolution documented in the literature.

\section{Funding}

R Colebunders obtained funding from VLIRUOS (Flemish Universities development aid).

\section{Availability of data and materials}

The datasets used and/or analysed during the current study are available from the corresponding author on reasonable request.
Consent for publication

Not applicable.

\section{Competing interests}

The authors declare no conflict of interest.

\section{Author details}

${ }^{1}$ School of Medicine, Health Sciences Unit, Federal University of Jataí, Jataí, Brazil. ${ }^{2}$ Center for Translational Research in Oncology, Institute of Cancer of São Paulo State, São Paulo, Brazil. ${ }^{3}$ Department of Epidemiology, School of Public Health, University of São Paulo, São Paulo, Brazil. ${ }^{4}$ Global Health Institute, University of Antwerp, Antwerp, Belgium

Received: 2 June 2020 Accepted: 12 January 2021

Published online: 18 January 2021

\section{References}

1. Zhu N, Zhang D, Wang W, et al. A novel coronavirus from patients with pneumonia in China, 2019. N Engl J Med. 2020:382:727-3.

2. Gorbalenya $A E$, et al. Severe acute respiratory syndrome-related coronavirus: the species and its viruses - a statement of the coronavirus study group. Microbiology. 2020.

3. World Health Organization. WHO Coronavirus Disease (COVID-19) Dashboard Available at: <https://covid19.who.int>. Access on: 31 dec 2020.

4. Wilson ME, Chen LH. Travelers give wings to novel coronavirus (2019-nCoV). J Travel Med. 2020.

5. World Health Organization. Coronavirus disease 2019 (COVID-19). Situational Report-37. Disponível em: <https://www.who.int/docs/default-source/ coronaviruse/ situation reports/20200226-sitrep-37-covid-19.pdf>. Accessed 27 Feb 2020.

6. Regmi K, Lwin CM. Impact of non-pharmaceutical interventions for reducing transmission of COVID-19: a systematic review and meta-analysis protocol. BMJ Open. 2020 Oct 22;10(10):e041383. https://doi.org/10.1136/bmjopen2020-041383.

7. Acuña-Zegarra MA, Santana-Cibrian M, Velasco-Hernandez JX. Modeling behavioral change and COVID-19 containment in Mexico: A trade-off between lockdown and compliance [published online ahead of print, 2020 May 6]. Math Biosci. 2020:108370. https://doi.org/10.1016/j.mbs.2020.108370.

8. Jarvis $\mathrm{Cl}$, Van Zandvoort K, Gimma A, et al. Quantifying the impact of physical distance measures on the transmission of COVID-19 in the UK. BMC Med. 2020;18(1):124. Published 2020 May 7. https://doi.org/10.1186/s12916020-01597-8.

9. Houghton C, Meskell P, Delaney H, et al. Barriers and facilitators to healthcare workers' adherence with infection prevention and control (IPC) guidelines for respiratory infectious diseases: a rapid qualitative evidence synthesis. Cochrane Database Syst Rev. 2020;4(4):CD013582. Published 2020 Apr 21. https://doi.org/10.1002/14651858.CD013582.

10. Hillier MD. Using effective hand hygiene practice to prevent and control infection. Nurs Stand. 2020;35(5):45-50. https://doi.org/10.7748/ns.2020. e11552.

11. Saitoh A, Sato K, Magara Y, et al. Improving Hand Hygiene Adherence in Healthcare Workers Before Patient Contact: A Multimodal Intervention in Four Tertiary Care Hospitals in Japan. J Hosp Med. 2020;15(5):262-7. https:// doi.org/10.12788/jhm.3446.

12. Ngonghala CN, Iboi E, Eikenberry S, et al. Mathematical assessment of the impact of non-pharmaceutical interventions on curtailing the 2019 novel coronavirus [published online ahead of print, 2020 may 1]. Math Biosci. 2020:325:108364. https://doi.org/10.1016/j.mbs.2020.108364.

13. West R, Michie S, Rubin GJ, Amlôt R. Applying principles of behaviour change to reduce SARS-CoV-2 transmission. Nat Hum Behav. 2020;4(5):4519. https://doi.org/10.1038/s41562-020-0887-9.

14. BRASIL. Ministério da Saúde. Secretaria de Vigilância em Saúde. Centro de Operações de Emergências em Saúde Pública. Boletim Epidemiológico Especial 14. 2020. Available online: www.saude.gov.br/bvs. Acessed on 30 Apr 2020

15. Wang Q, Yu C. The role of masks and respirator protection against SARSCoV-2. Infect Control Hosp Epidemiol. 2020;41(6):746-7. https://doi.org/10. 1017/ice.2020.83.

16. Noh JY, Seong H, Yoon JG, Song JY, Cheong HJ, Kim WJ. Social Distancing against COVID-19: Implication for the Control of Influenza. J Korean Med Sci. 
2020;35(19):e182. Published 2020 May 18. https://doi.org/10.3346/jkms.2020. 35.e182.

17. Zhong BL, Luo W, Li HM, et al. Knowledge, attitudes, and practices towards COVID-19 among Chinese residents during the rapid rise period of the COVID-19 outbreak: a quick online cross-sectional survey. Int J Biol Sci. 2020; 16(10):1745-52. Published 2020 Mar 15. https://doi.org/10.7150/ijbs.45221.

18. Siewe Fodjo JN, Pengpid S, Villela EFM, Van Thang V, Ahmed M, Ditekemena J, Crespo BV, Wanyenze RK, Dula J, Watanabe T, Delgado-Ratto C, Driessche KV, Van den Bergh R, Colebunders R. Mass masking as a way to contain COVID-19 and exit lockdown in low- and middle-income countries. J Inf Secur. 2020;81(3):e1-5. https://doi.org/10.1016/j.jinf.2020.07.015.

19. Hernández-García I, Giménez-Júlvez T. Assessment of Health Information About COVID-19 Prevention on the Internet: Infodemiological Study. JMIR Public Health Surveill. 2020;6(2):e18717. Published 2020 Apr 1. https://doi. org/10.2196/18717.

20. Geldsetzer P. Use of Rapid Online Surveys to Assess People's Perceptions During Infectious Disease Outbreaks: A Cross-sectional Survey on COVID-19. J Med Internet Res. 2020;22(4):e18790. Published 2020 Apr 2. https://doi.org/ 10.2196/18790.

21. Feng S, Shen C, Xia N, Song W, Fan M, Cowling BJ. Rational use of face masks in the COVID-19 pandemic. Lancet Respir Med. 2020;8(5):434-6. https://doi.org/10.1016/S2213-2600(20)30134-X.

22. World Health Organization. Available online: https://www.who.int/newsroom/articles-detail/updated-who-advice-for-international-traffic-in-relationto-the-outbreak-of-the-novel-coronavirus-2019-ncov-24-jan . Accessed on 24 May 2020.

23. Szwarcwald CL, Souza Júnior PRB, Malta DC, Barros MBA, Magalhães MAFM, Xavier DR, et al. Adesão às medidas de restrição de contato físico e disseminação da COVID-19 no Brasil. Epidemiol Serv Saúde. 2020;29(5): e2020432. Available from: http://www.scielo.br/scielo.php?script=sci_ arttext\&pid=\$2237-96222020000500305\&lng=en. Epub Nov 06, 2020. [cited 2021 Jan 06]. https://doi.org/10.1590/s1679-49742020000500018.

24. Prusaczyk B. Strategies for Disseminating and Implementing COVID-19 Public Health Prevention Practices in Rural Areas [published online ahead of print, 2020 Apr 3]. J Rural Health. 2020. https://doi.org/10.1111/jrh.12432.

25. Ranscombe P. Rural areas at risk during COVID-19 pandemic. Lancet Infect Dis. 2020;20(5):545. https://doi.org/10.1016/S1473-3099(20)30301-7.

26. Wang $P$, Lu J-A, Jin Y, Zhu M, Wang L, Chen S. Statistical and network analysis of 1212 COVID-19 patients in Henan, China. Int J Infect Dis. 2020.

27. Kuno Crative. Available online: https:/www.kunocreative.com/blog/ influencers-doing-good-during-covid-19. Accessed on 24 May 2020.

28. BRASIL. Ministério da Saúde. Secretaria de Vigilância em Saúde. Centro de Operações de Emergências em Saúde Pública. Plano de Contingência Nacional para Infecção Humana pelo novo Coronavírus COVID-19. 1. ed. 2020. Available online: www.saude.gov.br/bvs. Accessed on 24 Apr 2020.

29. Mellan TA, Hoeltgebaum HH, Mishra S, et al. Estimating COVID-19 cases and reproduction number in Brazil. Imperial College London; 2020. https://doi. org/10.25561/78872.

30. Giacomelli A, et al. 30-day mortality in patients hospitalized with COVID-19 during the first wave of the Italian epidemic: a prospective cohort study. Pharmacol Res. 2020;21:104931. https://doi.org/10.1016/.jphrs.2020.104931.

31. Asfahan $\mathrm{S}$, et al. Extrapolation of mortality in COVID-19: Exploring the role of age, sex, co-morbidities and health-care related occupation. Monaldi Arch Chest Dis. 2020;90(2). https://doi.org/10.4081/monaldi.2020.1325 PMID: 32447949

32. Valente, J. Covid-19: uso maior da internet requer mais cuidado com segurança. Agência Brasil. 2020. Available online: https://agenciabrasil.ebc. com.br/saude/noticia/2020-03/covid-19-uso-maior-da-internet-requer-maiscuidado-com-seguranca. Accessed on 30 Apr 2020.

33. COVID-19 in Brazil: "So what?". [editorial]. The Lancet. 2020; 395(10235):1461.

34. Matos CCSA, Barbieri CLA, Couto MT. Covid-19 and its impact on immunization programs: reflections from Brazil. Rev Saude Publica. 2020;54: 114.

35. Requia WJ, et al. Risk of the Brazilian health care system over 5572 municipalities to ex-ceed health care capacity due to the 2019 novel coronavirus (COVID-19). Sci Total Environ. 730(2020):139144

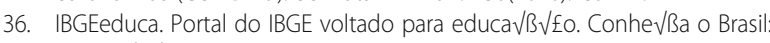
Popula $\sqrt{B} \sqrt{ }$ \& - Quantidade de homens e mulheres. Available online: https://educa.ibge.gov.br/jovens/conheca-o-brasil/populacao/18320quantidade-de-homens-e-mulheres.html. Accessed on 03 Jan 2021.
37. Comitê Gestor da Internet no Brasil. Núcleo de Informação e Coordenação do Ponto BR. Banda larga no Brasil: um estudo sobre a evolução do acesso e da qualidade das conexões à Internet /[coordenação executiva e editorial Alexandre F. Barbosa]. São Paulo: Available online: https://cetic.br/media/ docs/publicacoes/1/Estudo\%20Banda\%20Larga\%20no\%20Brasil.pdf. Accessed on 24 Apr 2020.

38. Lima CKT, et al. The emotional impact of coronavirus 2019-nCoV (new coronavirus disease). Psychiatry Res. 2020;287:112915.

39. El País. Pandemia de coronavirus. Mais de 30 países iniciaram vacinação contra covid-19, e Bolsonaro agora fala em pressa por vacina. Available online: https://brasil.elpais.com/brasil/2020-12-27/mais-de-30-paisesiniciaram-vacinacao-contra-covid-19-e-bolsonaro-agora-fala-em-pressa-porvacina.html. Accessed on 03 Jan 2021.

40. Guimarães R. Vacinas Anticovid: um Olhar da Saúde Coletiva. Ciênc. saúde coletiva [Internet]. 2020;25(9):3579-85. Available from: http://www.scielo.br/ scielo.php?script=sci_arttext\&pid=\$1413-81232020000903579\&lng=en. Epub Aug 28, 2020. [cited 2020 Dec 31]. https://doi.org/10.1590/141381232020259.24542020

\section{Publisher's Note}

Springer Nature remains neutral with regard to jurisdictional claims in published maps and institutional affiliations.
Ready to submit your research? Choose BMC and benefit from:

- fast, convenient online submission

- thorough peer review by experienced researchers in your field

- rapid publication on acceptance

- support for research data, including large and complex data types

- gold Open Access which fosters wider collaboration and increased citations

- maximum visibility for your research: over $100 \mathrm{M}$ website views per year

At BMC, research is always in progress.

Learn more biomedcentral.com/submissions 